\title{
Effect of milk kind on the physicochemical and sensorial properties of synbiotic kefirs containing Lactobacillus acidophilus LA-5 and Bifidobacterium bifidum BB-11 accompanied with inulin
}

\author{
İlkay BURAN ${ }^{1 *}$ (D), Havva Ceren AKAL ${ }^{1}$, Sebnem OZTURKOĞLU-BUDAK ${ }^{1}$, Atila YETISEMIYEN ${ }^{1}$
}

\begin{abstract}
In this study, synbiotic kefir types were produced by the addition of probiotic bacteria and prebiotics to cow and goat milk. Commercial DVS kefir cultures, Lactobacillus acidophilus LA-5, Bifidobacterium bifidum BB-11 as probiotic cultures and inulin as prebiotic for the production of the kefir samples. The effect of the different probiotics and prebiotic on some characteristics of kefir made from cow and goat milk was investigated. Titratable acidity, tyrosine content, volatile components and sensory properties of samples were examined on the $1^{\text {st }}, 7^{\text {th }}, 14^{\text {th }}$ and $21^{\text {st }}$ day of storage. According to the results, titratable acidity and tyrosine amount in kefir increased during the storage period. There was a gradual increase in the acetaldehyde value of kefir made from cow milk during the storage period, whereas there were no regular changes obtained in the kefir produced from goat milk. However, the diacetyl content varied in all the synbiotic products during storage. The total acceptability results showed that the synbiotic kefir made from cow milk was more preferred to the one made from goat milk.
\end{abstract}

Keywords: kefir; probiotic; prebiotic; inulin; synbiotic.

Practical Application: Synbiotic kefir production with different types of milk.

\section{Introduction}

The changes in lifestyle nowdays has led to a great interest in societies with regard to nutrition and food production with technology aiming at producing high nutritional foods that have a possible impact on health promotion. The positive effects of functional dairy products on health have attracted consumers' attention to functional foods, thus a significant increase in production by the dairy industry. There are 3 main approaches for the production of functional dairy products. These are: (i) probiotic, prebiotic-containing, or synbiotic dairy products (ii) enriched dairy products and (iii) energy-reduced dairy products (Sezen \& Kocak, 2006).

Probiotic foods are so important among functional foods. Probiotics are previously defined as living microorganisms that have beneficial effects on the health and physiology of people if taken in a certain amount (Hill et al., 2014). Probiotics are known as foods containing a sufficient number of living microorganisms in a given matrix. However, according to probiotic terminology in the recent years, 'probiotic' can be defined as 'a viable or inviable microbial cell (vegetative or spore; intact or torn) that potentially provides healthy to the host (Zendeboodi et al., 2020). The most widely preferred probiotics in the dairy industry are Lactobacillus spp. and Bifidobacterium spp. (Saxelin et al., 1999, de Vrese \& Schrezenmeir, 2001, Sarfraz et al., 2019). Prebiotics have been developed as components that benefit the health of the host by allowing specific changes in the activity and composition of the gastrointestinal flora (Ozyurt \& Otles, 2014). Prebiotics have potential of improving human and animal health and reduce the risk of disease caused by microbiota deviations also known as a substrate which have beneficial and selective effects on the host of microorganisms (Gibson et al., 2017). Before, the term 'synbiotic' is defined as an increase in the probiotic bacteria count as a result of the combination of these bacteria with prebiotics to show a synergistic action beneficial to health (Harish \& Varghese, 2006), but then definition was updated to "[...] a mixture comprising live microorganisms and substrate(s) selectively utilized by host microorganisms that confers a health benefit on the host [...]" (Swanson et al., 2020, p. 688). However, the effect of the synbiotic combination is much more than that of probiotic or prebiotic alone. Also, studies on synbiotics have shown positive effects on health. For instance, Shafi et al., (2019) determined that synbiotic milk has an in vitro antimicrobial and in vivo (in diabetic rabbits) antidiabetic effect. Therefore, it is recommended to use synbiotic products in the functional food market (Gibson \& Roberfroid, 1995, Ziemer \& Gibson, 1998, Holzapfel \& Schillinger, 2002, Konar et al., 2018).

Kefir is one of the foremost probiotic products in the dairy industry. It is a fermented milk drink produced from kefir grains containing microorganisms in a complex and specific mixture of polysaccharide matrix, which has a fresh and slightly acidic taste. Kefir is usually produced from cow's milk, but it can also be successfully made from sheep milk (Larosa et al., 2021a; de Lima et al., 2018), buffalo milk (Tomar et al., 2020) and colostrum (Setyawardani, et al., 2020). This fermented milk drink is different from other fermented milk products in terms of the complex 
metabolic activity based on several microbial species as well as the production methods of the kefir grains (Farnworth \& Mainville, 2008). Lactic acid bacteria (LAB) and yeast isolated from kefir grains are the major components of kefir starter culture (Simova et al., 2002; Beshkova et al., 2003). Although Lactobacillus species represent the main bacterial group in kefir, other LAB, yeasts, and acetic acid bacteria also contribute to its unique aroma (Arslan, 2015). In addition, even there are many different Lactobacillus species are in the structure of kefir, in case of probiotic supplement $L b$. rhamnosus is also preferred since kefir is a good carrier of this species (Mitra \& Ghosh, 2020). The chemical composition, nutritional value, sensory properties, and aroma of kefir depends mainly on the production conditions, the qualities of the raw milk, structure of the kefir grains or starter culture, fermentation time, and the storage conditions (Zourari et al., 1988, Wszolek et al., 2001, Oner et al., 2010). Traditional kefir has many beneficial influences on the immune system and digestive/gastrointestinal tract lowering cholesterol, allergies, wound healing, ACE inhibition, preventing lactose intolerance causing antimutagenic, anticarcinogenic and antimicrobial effects on human health. Despite all these health benefits, there is a need to evaluate the possibility of the species isolated from kefir grain especially yeasts regarding the cause of opportunistic infections (Lim et al., 2019).

The most widespread and commercially used prebiotics is inulin, a polydisperse carbohydrate that is stable in medium acidity in the range of $\mathrm{pH} 4.0-5.0$. Since inulin does not irreversibly react with the product during processing, it is usually used in fermented milk products (Debon et al., 2010). Inulin is also used as a sweetener, sugar substitute, texture improver, and gelling agent in various foods (Pompei et al., 2008). Inulin has both beneficial effects on health and improve rheological and sensory properties of products that is supplemented (Esmaeilnejad Moghadam et al., 2019). The interaction of bacteria and yeast in kefir grain forms the sensory quality of the product, and the controlled aroma formation occurs with the use of starter culture (Beshkova et al., 2003). Lactic acid, ethanol, carbondioxide, and other flavor compounds such as acetaldehyde, diacetyl, and acetoin are produced as a result of kefir fermentation (Altay et al., 2013 ) with the ethanol content of kefir $(0.035 \%-2 \%)$ being the most in quantity (Guzel-Seydim et al., 2010).

The primary purpose of this study is to compare the physicochemical, sensory properties, aroma components, and tyrosine amounts of synbiotic kefir made from cow and goat milk during the storage period.

\section{Materials and methods}

\subsection{Materials}

The cow milk used for the production of kefir was obtained from Ankara University, Dairy Factory (Ankara, Turkey), and the goat milk was obtained from Atatürk Forest Farm (AFF) Dairy Factory (Ankara, Turkey). Kefir-2 starter culture (Debaryomyces hansenii, Lactococcus lactis subsp. cremoris, Lactococcus lactis subsp. lactis, Lactococcus lactis subsp.), Lactobacillus acidophilus LA-5 and Bifidobacterium bifidum BB-11 were provided by Chr. Hansen Company (Horsholm, Denmark). The inulin used as prebiotic was obtained from Artısan Gida San. Tic. Ltd. (Beneo-Manheim, Germany).

\subsection{Kefir production}

The cow milk (CM) (dry matter value was $11.71 \%$, fat ratio $3.70 \%$, protein ratio $3.50 \%$ and ash ratio $0.64 \%, \mathrm{pH}$ value 6.72 ) and the goat milk (GM) (dry matter value was $12.81 \%$ ) fat ratio $3.95 \%$, protein ratio $4.01 \%$ and ash ratio $0.65 \%$, pH value 6.81) was used for the production of synbiotic kefir in the given physicochemical properties. Productions were performed according to the flow chart given in Figure 1 below. Samples were analyzed in replicate on day $1^{\text {st }}, 7^{\text {th }}, 14^{\text {th }}$, and $21^{\text {st }}$ day of storage.

\subsection{Physicochemical properties}

The dry matter (\%) analyses were performed by using the gravimetric method (Food and Agriculture Organization of the United Nations, 2002) in the oven at $100^{\circ} \mathrm{C}$. Protein content (\%) was determined by the Kjeldahl method (International Dairy Federation Standard, 1962), and fat content (\%) was measured by the Gerber-Van Gulik method (Institute of Turkish Standards,

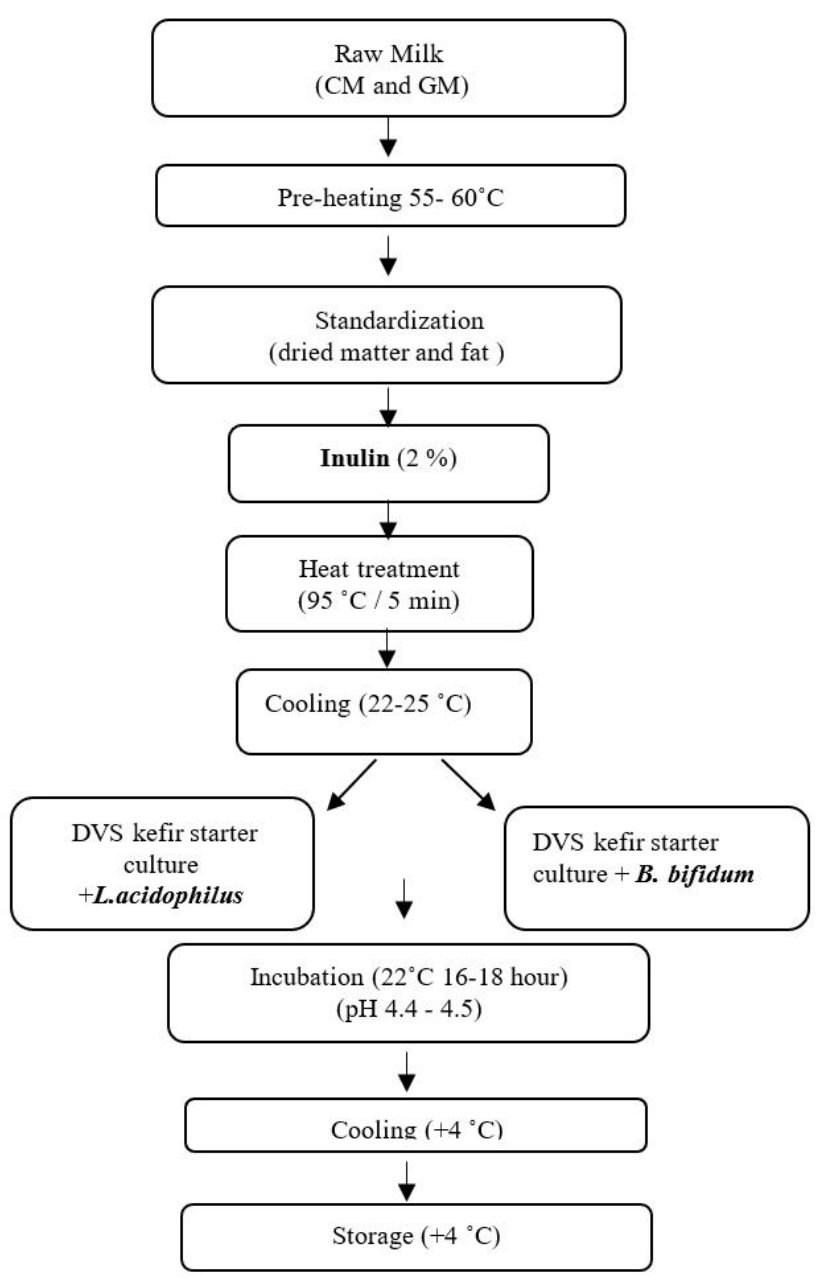

Figure 1. Flow chart of synbiotic kefir production made from cow and goat milk. 
1990). The amount of tyrosine was calculated according to Hull (1947) by using the UV-Vis Spectrophotometer (at $650 \mathrm{~nm}$ ) (Perkin Elmer, Massachusetts, USA).

\subsection{Determination of volatile compounds}

Volatile compound analysis was carried out by the Gas Chromatography (6890 series GC, Agilent Technologies, Santa Clara, CA) using the headspace technique according to the method specified by Ulberth (1991). The GC system was equipped with a flame ionization detector (FID) and a polyethylene glycol capillary column (HP-Innowax, $30 \mathrm{~m} \times 320 \mu \mathrm{m} \times 0.25 \mu \mathrm{m}$ film thickness, Agilent Technologies). In the analysis, $5 \mathrm{~g}$ of kefir sample was weighed into $20 \mathrm{~mL}$ vials, sealed, and heated at $80^{\circ} \mathrm{C}$ for 20 minutes in a dry block heater (Thermo Fisher Scientific, Waltham, MA) before injection into the GC. $1000 \mu \mathrm{L}$ of air on top of the gas-tight injector was injected into the GC.

The operating conditions of the GC system were regulated as follows:

The inlet temperature and the flame ionization detector temperature were at $80^{\circ} \mathrm{C}$ and $260^{\circ} \mathrm{C}$, respectively. The flow rates for compensating gas make-up gas (nitrogen), hydrogen, and air used were 30,40 , and $400 \mathrm{~mL} / \mathrm{min}$, respectively. The flow rate of the carrier gas (helium) was $0.7 \mathrm{~mL} / \mathrm{min}$. Initially, the oven was held at $80^{\circ} \mathrm{C}$ for 1 minute and the temperature was raised for $1 \mathrm{~min}$ by increasing the temperature from $5^{\circ} \mathrm{C}$ to $170^{\circ} \mathrm{C}$ per minute. Then it raised to a final temperature of $210^{\circ} \mathrm{C}$ in an increment of $10^{\circ} \mathrm{C}$ per minute to give a 24 minute run time. Calibration curves were generated according to the calibration solutions of $10,25,50,75$, and $100 \mathrm{mg} / \mathrm{L}$ for the quantitative determination of each flavor compound. All samples were injected twice.

\subsection{Sensory analysis}

The hedonic type scale determined by Clark \& Costello (2016) was used for the sensory evaluation of kefir samples. Kefir samples were served to 7 trained panelist groups in transparent $50 \mathrm{~mL}$ plastic cups to evaluate for its appearance, structure, and taste characteristics. The sensory properties of kefir samples were examined on the $1^{\text {st }}, 7^{\text {th }}, 14^{\text {th }}$ and $21^{\text {st }}$ day of storage. The panelists evaluated the samples according to the scoring system ranging points from 1 to 5 .

\subsection{Statistical evaluation}

Statistical evaluation of the study (ANOVA) was performed by Minitab package program (version Minitab ${ }^{\circledR} 16.1 .1$, Minitab Inc., State College, PA) according to the repeated measurement variance analysis technique used in the random blocks trial setup. Tukey's test was conducted at the level of $\mathrm{p}<0.05$ to determine the groups with differences.

\section{Results and discussion}

\subsection{Chemical properties}

Due to the compositions of the milk used during the productions, the dry matter (DM) contents of kefir made from cow and goat milk differed from each other $(\mathrm{p}<0.05)$ (Table 1). Some study results on kefir made from cow and goat milk had similar dry matter values like our study (Oner et al., 2010; Satır \& Guzel-Seydim, 2016), or kefir made from cow milk (Barukcic et al., 2017). On the other hand, the results of Kök-Taş et al. (2013) on cow milk kefir and Silveira et al. (2015) study on goat milk kefir had different results from our findings. However, these differences were due to the materials used in the studies. A similar study carried out by Kök-Taş et al. (2013) produced lower values than our study since skimmed kefir was produced. Also, Silveira et al. (2015) found higher dry matter values because they used whey powder in addition to the prebiotic. The fat and protein amount found in our study were above the limit values stated by the Fermented Dairy Products Communiqué (Food and Agriculture Organization of the United Nations, 2009). However, the fat and protein amount were found to be proportional to the DM contents of the products.

\subsection{Titratable acidity}

The acidity values of kefir made from cow milk were found to be between $36.59-37.47^{\circ} \mathrm{SH}$ ) and $43.24-45.54^{\circ} \mathrm{SH}$ for the goat milk kefir samples (Table 2). The lactic acid contents of the kefir samples was similar to the findings determined by Kök-Taş et al. (2013) and Silveira et al. (2015). The increment of titratable acidity in kefir could be as a result of microbial proteolysis with the activity of lactic acid bacteria or yeasts in the storage period (Guzel-Seydim et al., 2005). The reason for the higher titratable acidity of kefir samples obtained from goat milk could be explained by the higher dry matter and protein content in goat milk compared to cow milk. Shafiee et al. (2010) showed that the viability of $L$. acidophilus and Bifidobacteria was affected by the dry matter ratio since higher amounts of dry matter possessed greater viability of probiotic bacteria.

\subsection{Tyrosine content}

In fermented milk products such as kefir, microorganisms exist in the structure of starter cultures that hydrolyze proteins to peptides and amino acids as a result of proteolytic activities.

Table 1. Chemical properties of synbiotic kefir samples (\% w/w).

\begin{tabular}{lcccc}
\hline & CMLA & CMBB & GMLA & GMBB \\
\hline Dry Matter $(D M)$ content & $13.90 \pm 0.56^{\mathrm{b}}$ & $13.94 \pm 0.09^{\mathrm{b}}$ & $17.01 \pm 0.35^{\mathrm{a}}$ & $16.92 \pm 0.24^{\mathrm{a}}$ \\
Fat Content & $3.55 \pm 0.05$ & $3.55 \pm 0.05$ & $4.20 \pm 0.25$ & $4.10 \pm 0.10$ \\
Protein Content & $3.10 \pm 0.12^{\mathrm{b}}$ & $3.07 \pm 0.09^{\mathrm{b}}$ & $4.04 \pm 0.05^{\mathrm{a}}$ & $3.99 \pm 0.04^{\mathrm{a}}$ \\
\hline
\end{tabular}

CMLA: Sample made from cow milk with kefir culture, L. acidophilus La-5 and inulin, CMBB: Sample made from cow milk with kefir culture, B.bifidum BB-11 and inulin; GMLA: Sample

made from goat milk with kefir culture, L. acidophilus La-5 and inulin, GMBB: Sample made from goat milk with kefir culture, B.bifidum BB-11 and inulin 
Tyrosine is one of the amino acids that are the end-product of this reaction. Therefore, the tyrosine value is among the parameters performed as the level of proteolysis, and the degree of ripening is explained in the literature as the total amount of amino acids released as a result of proteolysis (Tamime \& Deeth, 1980). The significant interaction between samples and storage days $(\mathrm{P}<0.05)$ was determined in terms of tyrosine values, and the differences are shown in Table 3 . The difference between the tyrosine values of the samples obtained from goat milk (GMLA, GMBB) was found insignificant at $(\mathrm{P}>0.05)$. Tyrosine values of kefir samples obtained from cow milk showed a significant decrease during the storage due to the higher proteolytic activity of cow milk kefir compared to that of the goat milk.

\subsection{Sensorial properties}

Consumers usually expect some varied features in the texture, flavor/taste balance, aroma and appearance of products. Scoring tests are the most common methods to reveal the sensory characteristics of a product in order to determine the consumer preference. In addition, there are new techniques such as free word association (Judacewski et al., 2019) or emotional profiling (Larosa et al., 2021b) that have been developed in recent years.

The sensory evaluation results are given in Table 4. According to the sensory evaluation, there was no significant difference between both samples during the storage days for all parameters (appearance, body, taste, total acceptability) $(\mathrm{P}>0.05)$. The body scores of kefir obtained from cow milk were higher than that of goat milk in all the storage days. Consumers preferred kefir derived from cow's milk in terms of body features. Similarly, kefir samples obtained from cow milk had higher taste scores. Cow milk kefir was liked more than other samples according to the total acceptability results. No difference was observed between the sensory properties of cow milk kefir produced using L. acidophilus or B. bifidum. Consumer appreciation increased with the storage, especially for the goat milk samples (GMLA and $\mathrm{GMBB}$ ), and had the highest value on the $21^{\text {st }}$ day of storage.
GMLA and GMBB samples also had the highest tyrosine and titratable acidity value on the same day. Sensory analysis results showed that these values was preferred by the consumers.

\subsection{Volatile compounds}

Acetaldehyde is known as the yogurt flavor, and it is also responsible for the fruity and alcoholic flavor in dairy products, including kefir. The volatile compounds results are given in Table 5. The acetaldehyde values detected in all the kefir samples varied from 1.70 to $33.7 \mathrm{ppm}$. Whereas the acetaldehyde concentration in kefir produced from cow milk showed a regular increase during storage, fluctuations were observed in kefir obtained from goat milk. Guzel-Seydim et al. (2000) reported that $25 \mathrm{ppm}$ acetaldehyde was determined at the end of fermentation (22 h) in a study that revealed the formation of aroma components in kefir during fermentation. Beshkova et al. (2003) stated that they found acetaldehyde between 5.60-18.10 ppm in kefir samples. The reason for the more acetaldehyde detection in our study could be the synbiotic properties of the samples, unlike for the other studies. Similarly, the amount of diacetyl responsible for the typical butter flavor fluctuated during storage. Beshkova et al. (2003) stated that they found diacetyl between 1.00-1.85 ppm in kefir samples. However, the microflora of kefir culture or grain used in production directly affects the amount of flavor compounds. The difference seen in our study is thought to be due to the differences in the microbial cultures.

Ethanol is an important aroma compound produced by yeasts in kefir and it is also responsible for a fresh aroma in dairy products. Similar to diacetyl, the microbial differences of culture or grain used in kefir production, the ethanol value in kefir samples may vary in a wide range such as $0.00-76.5$ ppm (Kök-Taş et al., 2013; Gul et al., 2015). In this study, the ethanol value in the kefir samples was between 0.00 and $2.60 \mathrm{ppm}$. Whereas ethanol was not found in all samples at the beginning of storage, it was detected in the following storage days. However, the ethanol values fluctuated during storage except for the GMBB sample.

Table 2. Titratable values of synbiotic kefir samples ( $\left.{ }^{\circ} \mathrm{SH}\right)$.

\begin{tabular}{ccccc}
\hline Storage (Days) & CMLA & CMBB & GMLA & GMBB \\
\hline $\mathbf{1}$ & $36.59 \pm 0.37$ & $36.86 \pm 0.48$ & $44.53 \pm 0.42$ & $43.24 \pm 1.36$ \\
$\mathbf{7}$ & $36.75 \pm 0.66$ & $36.99 \pm 0.17$ & $45.26 \pm 0.20$ & $44.65 \pm 0.16$ \\
$\mathbf{1 4}$ & $36.77 \pm 0.01$ & $37.21 \pm 0.07$ & $45.34 \pm 0.68$ & $45.37 \pm 0.40$ \\
$\mathbf{2 1}$ & $37.46 \pm 0.60$ & $37.47 \pm 0.56$ & $45.63 \pm 0.14$ & $45.54 \pm 0.24$ \\
\hline
\end{tabular}

CMLA: Sample made from cow milk with kefir culture, L. acidophilus La-5 and inulin, CMBB: Sample made from cow milk with kefir culture, B.bifidum BB-11 and inulin; GMLA: Sample made from goat milk with kefir culture, L. acidophilus La-5 and inulin, GMBB: Sample made from goat milk with kefir culture, B.bifidum BB-11 and inulin

Table 3. Tyrosine contents of synbiotic kefir samples ( $\mathrm{mg} / 5 \mathrm{~g})$.

\begin{tabular}{ccccc}
\hline Storage (Days) & CMLA & CMBB & GMLA & GMBB \\
\hline $\mathbf{1}$ & $0.39 \pm 0.02^{\mathrm{C}}$ & $0.34 \pm 0.01^{\mathrm{C}}$ & $0.20 \pm 0.01^{\mathrm{C}}$ & $0.19 \pm 0.03^{\mathrm{C}}$ \\
$\mathbf{7}$ & $0.39 \pm 0.05^{\mathrm{C}}$ & $0.50 \pm 0.04^{\mathrm{BC}}$ & $0.21 \pm 0.01^{\mathrm{C}}$ & $0.22 \pm 0.00^{\mathrm{C}}$ \\
$\mathbf{1 4}$ & $0.47 \pm 0.16^{\mathrm{BC}}$ & $0.81 \pm 0.07^{\mathrm{AB}}$ & $0.21 \pm 0.01^{\mathrm{C}}$ & $0.23 \pm 0.02^{\mathrm{C}}$ \\
$\mathbf{2 1}$ & $0.49 \pm 0.03^{\mathrm{BC}}$ & $0.90 \pm 0.16^{\mathrm{A}}$ & $0.31 \pm 0.05^{\mathrm{C}}$ & $0.28 \pm 0.01^{\mathrm{C}}$ \\
\hline
\end{tabular}

CMLA: Sample made from cow milk with kefir culture, L. acidophilus La-5 and inulin, CMBB: Sample made from cow milk with kefir culture, B.bifidum BB-11 and inulin; GMLA: Sample made from goat milk with kefir culture, L. acidophilus La-5 and inulin, GMBB: Sample made from goat milk with kefir culture, B.bifidum BB-11 and inulin. 
Table 4. Sensorial properties of synbiotic kefir samples.

\begin{tabular}{lccccc}
\hline \multicolumn{1}{c}{ Sensorial Property } & Storage (Days) & CMLA & CMBB & GMLA & GMBB \\
\hline Appearence & $\mathbf{1}$ & $4.80 \pm 0.10$ & $5.00 \pm 0.00$ & $5.00 \pm 0.00$ & $5.00 \pm 0.00$ \\
& 7 & $4.85 \pm 0.15$ & $4.90 \pm 0.10$ & $4.90 \pm 0.00$ & $4.90 \pm 0.00$ \\
& $\mathbf{1 4}$ & $4.95 \pm 0.05$ & $4.70 \pm 0.10$ & $4.90 \pm 0.10$ & $4.90 \pm 0.10$ \\
Body & $\mathbf{2 1}$ & $4.95 \pm 0.05$ & $4.85 \pm 0.05$ & $5.00 \pm 0.00$ & $5.00 \pm 0.00$ \\
& $\mathbf{1}$ & $4.50 \pm 0.10$ & $4.80 \pm 0.10$ & $3.90 \pm 0.05$ & $3.80 \pm 0.25$ \\
& 7 & $4.60 \pm 0.20$ & $4.35 \pm 0.35$ & $3.80 \pm 0.35$ & $4.00 \pm 0.20$ \\
Taste & $\mathbf{1 4}$ & $4.50 \pm 0.20$ & $4.30 \pm 0.60$ & $3.50 \pm 0.10$ & $3.50 \pm 0.00$ \\
& $\mathbf{2 1}$ & $4.50 \pm 0.20$ & $4.60 \pm 0.10$ & $4.10 \pm 0.40$ & $4.00 \pm 0.50$ \\
& $\mathbf{1}$ & $3.60 \pm 0.20$ & $3.55 \pm 0.45$ & $3.60 \pm 0.05$ & $3.50 \pm 0.30$ \\
Total Acceptability & $\mathbf{1 4}$ & $3.30 \pm 0.10$ & $3.10 \pm 0.00$ & $3.00 \pm 0.05$ & $3.00 \pm 0.15$ \\
& $\mathbf{1 4}$ & $3.25 \pm 0.45$ & $3.60 \pm 0.10$ & $2.70 \pm 0.15$ & $3.00 \pm 0.20$ \\
& $\mathbf{2 1}$ & $3.50 \pm 0.50$ & $3.55 \pm 0.30$ & $3.80 \pm 0.00$ & $3.50 \pm 0.00$ \\
& $\mathbf{1}$ & $4.30 \pm 0.13$ & $4.45 \pm 0.18$ & $4.10 \pm 0.03$ & $4.10 \pm 0.18$ \\
& $\mathbf{1 4}$ & $4.25 \pm 0.08$ & $4.12 \pm 0.15$ & $3.90 \pm 0.10$ & $3.90 \pm 0.12$ \\
\end{tabular}

CMLA: Sample made from cow milk with kefir culture, L. acidophilus La-5 and inulin, CMBB: Sample made from cow milk with kefir culture, B.bifidum BB-11 and inulin; GMLA: Sample made from goat milk with kefir culture, L. acidophilus La-5 and inulin, GMBB: Sample made from goat milk with kefir culture, B.bifidum BB-11 and inulin.

Table 5. Volatile compounds of synbiotic kefir samples (ppm).

\begin{tabular}{lcccrr}
\hline Volatile compound & Storage (Days) & CMLA & CMBB & GMLA & GMBB \\
\hline Acetaldehyde & 1 & $1.70 \pm 0.56$ & $4.23 \pm 0.51$ & $16.04 \pm 0.53$ & $4.62 \pm 0.34$ \\
& 7 & $5.84 \pm 0.25$ & $10.1 \pm 1.25$ & $8.44 \pm 1.09$ & $16.55 \pm 0.26$ \\
& 14 & $12.7 \pm 2.35$ & $15.1 \pm 0.96$ & $0.00 \pm 0.00$ & $0.00 \pm 0.00$ \\
Diacetyl & 21 & $16.2 \pm 1.80$ & $33.7 \pm 1.54$ & $0.00 \pm 0.00$ & $0.00 \pm 0.00$ \\
& 1 & $1.53 \pm 0.17$ & $2.45 \pm 0.15$ & $4.33 \pm 0.00$ & $4.62 \pm 0.80$ \\
& 7 & $1.08 \pm 0.12$ & $0.98 \pm 0.18$ & $2.61 \pm 0.19$ & $3.27 \pm 0.38$ \\
Ethanol & 14 & $2.98 \pm 0.83$ & $3.03 \pm 0.58$ & $2.30 \pm 0.20$ & $1.95 \pm 0.30$ \\
& 21 & $3.18 \pm 1.73$ & $2.50 \pm 0.80$ & $2.575 \pm 0.43$ & $2.15 \pm 0.60$ \\
& 1 & $0.00 \pm 0.00$ & $0.00 \pm 0.00$ & $0.00 \pm 0.00$ & $0.00 \pm 0.00$ \\
& 7 & $2.15 \pm 0.28$ & $0.00 \pm 0.00$ & $1.05 \pm 1.05$ & $0.88 \pm 0.88$ \\
& 14 & $0.75 \pm 0.05$ & $0.00 \pm 0.00$ & $2.60 \pm 0.25$ & $2.15 \pm 0.20$ \\
\hline
\end{tabular}

CMLA: Sample made from cow milk with kefir culture, L. acidophilus La-5 and inulin, CMBB: Sample made from cow milk with kefir culture, B. bifidum BB-11 and inulin; GMLA: Sample made from goat milk with kefir culture, L. acidophilus La-5 and inulin, GMBB: Sample made from goat milk with kefir culture, B. bifidum BB-11 and inulin.

In the GMBB sample, ethanol value increased during storage. The results show that the use of goat milk might have a positive effect on ethanol formation. In regards to the aroma, the difference between ethanol values was found significant $(p<0.05)$ both among the samples and storage days. However, the difference between the samples or storage days in both acetaldehyde and diacetyl values was found insignificant $(p>0.05)$. Ethanol was not detected on any storage day of $\mathrm{CMBB}$, while the highest average ethanol value (1.50 ppm) was found in GMLA sample and the differences between these two samples were significant $(\mathrm{p}<0.05)$. Additionally, the difference between the other samples was not found significant in terms of ethanol $(p>0.05)$. In terms of ethanol amount, the difference between the first $(0.00 \mathrm{ppm})$ and last day $(1.40 \mathrm{ppm})$ of storage was found significant which means ethanol value was increased during this period.

\section{Conclusion}

In this study, synbiotic kefirs enriched with inulin as prebiotic and Lactobacillus acidophilus or Bifidobacterium bifidum as probiotic bacteria were produced using cow and goat milk.

According to the results, the titratable acidity value and the amount of tyrosine tended to increase until the $21^{\text {st }}$ day of storage in all of the kefir samples (CMLA, CMBB, GMLA, and GMBB). The acetaldehyde concentrations of cow milk kefir regularly increased during storage. However, fluctuations were observed in kefir made from goat milk. The amount of diacetyl varied in all samples during storage. Among the aroma compounds, its only ethanol concentration had a significant difference, and the use of goat milk had a positive effect on ethanol formation. Furthermore, the total acceptability results in terms of sensory 
evaluation, synbiotic kefir obtained from cow milk had the highest scores.

According to Kolida \& Gibson (2011), a synergistic synbiotic activity occurs when the probiotic is chosen based on specific beneficial effects on the host, but the prebiotic is chosen to specifically stimulate growth and activity of the selected probiotic. Whereas, a complementary synbiotic action occurs when the probiotic is chosen based on specific desired beneficial effects on the host, and the prebiotic is independently chosen to selectively increase concentrations of the beneficial microbiota components. Inulin is a selectively prebiotic for both Lactobacillus (Lépine and de Vos, 2018; Xavier-Santosa et al., 2019) and Bifidobacterium (Kondepudi et al., 2012; Ustundag et al., 2017). The results of this study also showed that synbiotic kefir samples with Lactobacillus acidophilus or Bifidobacterium bifidum accompanied with inulin have synergistic synbiotic properties.

\section{Acknowledgements}

This research was supported by the "Scientific Research Project Office of Ankara University" through the project number $16 \mathrm{~B} 0447003$.

\section{References}

Altay, F., Karbancioglu-Guler, F., Daskaya-Dikmen, C., \& Heperkan, D. (2013). A review on traditional Turkish fermented non-alcoholic beverages: microbiota, fermentation process and quality characteristics. International Journal of Food Microbiology, 167(1), 44-56. http:// dx.doi.org/10.1016/j.ijfoodmicro.2013.06.016. PMid:23859403.

Arslan, S. (2015). A review: chemical, microbiological and nutritional characteristics of kefir. Journal of Food, 13(3), 340-345. http://dx.doi. org/10.1080/19476337.2014.981588.

Barukcic, I., Gracin, L., Jambrak, A. R., \& Bozanic, R. (2017). Comparison of chemical, rheological and sensory properties of kefir produced by kefir grains and commercial kefir starter. Mljekarstvo, 67, 169-176. http://dx.doi.org/10.15567/mljekarstvo.2017.0301.

Beshkova, D. M., Simova, E. D., Frengova, G. I., Simov, Z. I., \& Dimitrov, Zh. P. (2003). Production of volatile aroma compounds by kefir starter cultures. International Dairy Journal, 13(7), 529-535. http:// dx.doi.org/10.1016/S0958-6946(03)00058-X.

Clark, S., \& Costello, M. (2016). Dairy products evaluation competitions. In S. Clark, M. Costello, M. A. Drake \& F. Bodyfelt (Eds.), The sensory evaluation of dairy products (2nd ed., pp. 43-72). USA: Springer Science Business Media.

de Lima, M. S. F., da Silva, R. A., da Silva, M. F., da Silva, P. A. B., Costa, R. M. P. B., Teixeira, J. A. C., Porto, A. L. F., \& Cavalcanti, M. T. H. (2018). Brazilian kefir-fermented sheep's milk, a source of antimicrobial and antioxidant peptides. Probiotics and Antimicrobial Proteins, 10(3), 446-455. http://dx.doi.org/10.1007/s12602-0179365-8. PMid:29285743.

de Vrese, M., \& Schrezenmeir, J. (2001, May-June). Pro and prebiotics. Chicago: Institute of Food Technologists.

Debon, J., Prudêncio, E. S., \& Cunha Petrus, J. C. (2010). Rheological and physico-chemical characterization of prebiotic microfiltered fermented milk. Journal of Food Engineering, 99(2), 128-135. http:// dx.doi.org/10.1016/j.jfoodeng.2010.02.008.

Esmaeilnejad Moghadam, B., Keivaninahr, F., Fouladi, M., Rezaei Mokarram, R., \& Nazemi, A. (2019). Inulin addition to yoghurt: prebiotic activity, health effects and sensory properties. International Journal of Dairy Technology, 72(2), 183-198. http://dx.doi. org/10.1111/1471-0307.12579.

Farnworth, E. R., \& Mainville, I. (2008). Kefir: a fermented milk product. In E. R. Farnworth (Ed.), Handbook of fermented functional foods (2nd ed., pp. 90-118). Boca Raton: CRC Press. http://dx.doi. org/10.1201/9781420053289

Food and Agriculture Organization of the United Nations - FAO, \& World Health Organization - WHO. (2002). CODEX standard for fermented milks. Rome: FAO.

Food and Agriculture Organization of the United Nations - FAO. (2009). Turkish Food Codex. Fermented Dairy Products Communiqué, Communiqué No: 2009/25. Rome: FAO.

Gibson, G. R., \& Roberfroid, M. B. (1995). Dietary modulation of the human colonic microbiota: Introducing the concept of prebiotics. The Journal of Nutrition, 125(6), 1401-1412. http://dx.doi.org/10.1093/ jn/125.6.1401. PMid:7782892.

Gibson, G. R., Hutkins, R., Sanders, M. E., Prescott, S. L., Reimer, R. A., Salminen, S. J., Scott, K., Stanton, C., Swanson, K. S., Cani, P. D., Verbeke, K., \& Reid, G. (2017). The International Scientific Association for Probiotics and Prebiotics (ISAPP) consensus statement on the definition and scope of prebiotics. Nature Reviews. Gastroenterology \& hepatology, 14(8), 491-502. PMid:28611480.

Gul, O., Mortas, M., Atalar, I., Dervisoglu, M., \& Kahyaoglu, T. (2015). Manufacture and characterization of kefir made from cow and buffalo milk, using kefir grain and starter culture. Journal of Dairy Science, 98(3), 1517-1525. http://dx.doi.org/10.3168/jds.2014-8755. PMid:25582588.

Guzel-Seydim, Z. B., Seydim, A. C., Greene, A. K., \& Bodine, A. B. (2000). Determination of organic acids and volatile flavor substances in kefir during fermantation. Journal of Food Composition and Analysis, 13(1), 35-43. http://dx.doi.org/10.1006/jfca.1999.0842.

Guzel-Seydim, Z. B., Wyffels, J. T., Seydim, A. C., \& Greene, A. K. (2005). Turkish kefir and kefir grains: microbial enumeration and electron microscobic observation. International Journal of Dairy Technology, 58(1), 25-29. http://dx.doi.org/10.1111/j.1471-0307.2005.00177.x.

Guzel-Seydim, Z., Kok-Tas, T., \& Greene, A. K. (2010). Kefir and koumiss: microbiology and technology. In F. Yildız (Ed.), Development and manufacture of yogurt and other functional dairy products (pp. 143164). Routledge: Taylor \& Francis Group.

Harish, K., \& Varghese, T. (2006). Probiotics, humans-evidencebased review. Calicut Medical Journal, 4, e3.

Hill, C., Guarner, F., Reid, G., Gibson, G. R., Merenstein, D. J., Pot, B., Morelli, L., Canani, R. B., Flint, H. J., Salminen, S., Calder, P. C., \& Sanders, M. E.. (2014). Expert consensus document: the international scientific association for probiotics and prebiotics consensus statement on the scope and appropriate use of the term probiotic. Nature Reviews. Gastroenterology \& Hepatology, 11(8), 506-514. http://dx.doi.org/10.1038/nrgastro.2014.66. PMid:24912386.

Holzapfel, W. H., \& Schillinger, U. (2002). Introduction to prebiotics and probiotics. Food Research International, 35(2-3), 109-116. http:// dx.doi.org/10.1016/S0963-9969(01)00171-5.

Hull, M. E. (1947). Studies on milk proteins. II Colorimetric determination of the partial hydrolysis of the protein in milk. Journal of Dairy Science, 30(11), 881-884. http://dx.doi.org/10.3168/jds.S00220302(47)92412-0.

Institute of Turkish Standards. (1990). TS (8189): determination of milk fat gerber method. Ankara: Institute of Turkish Standards. 
International Dairy Federation Standard - IDF. (1962). Determination of the total nitrogen content of milk by the Kjeldahl method (No: 20). Brussels: IDF.

Judacewski, P., Los, P. R., Lima, L. S., Albertı, A., Zielinski, A. A. F., \& Nogueira, A. (2019). Perceptions of Brazilian consumers regarding White mould surface-ripened cheese using free Word association. International Journal of Dairy Technology, 72(4), 585-590. http:// dx.doi.org/10.1111/1471-0307.12649.

Kök-Taş, T., Seydim, A. C., Ozer, B., \& Guzel-Seydim, Z. B. (2013). Effects of different fermentation parameters on quality characteristics of kefir. Journal of Dairy Science, 96(2), 780-789. http://dx.doi. org/10.3168/jds.2012-5753. PMid:23245957.

Kolida, S., \& Gibson, G. R. (2011). Synbiotics in Health and Disease. Annual Review of Food Science and Technology, 2(1), 373-393. http:// dx.doi.org/10.1146/annurev-food-022510-133739. PMid:22129388.

Konar, N., Palabiyik, I., Toker, O. S., Genc Polat, D., Kelleci, E., Pirouzian, H. R., Akcicek, A., \& Sagdic, O. (2018). Conventional and sugar-free probiotic white chocolate: Effect of inulin DP on vari- ous quality properties and viability of probiotics. Journal of Functional Foods, 43, 206-213. http://dx.doi.org/10.1016/j.jff.2018.02.016.

Kondepudi, K. K., Ambalam, P., Nilsson, I., Wadström, T., \& Ljungh, A. (2012). Prebiotic-non-digestible oligosaccharides preference of probiotic bifidobacteria and antimicrobial activity against Clostridium difficile. Anaerobe, 18(5), 489-497. http://dx.doi.org/10.1016/j. anaerobe.2012.08.005. PMid:22940065.

Larosa, C. P., Balthazar, C. F., Jonas, T., Guimarães, J. T., Margalho, L. P., Lemos, F. S., Oliveira, F. L., Abud, Y. K. D., Sant'Anna, C., Duarte, M. C. K. H., Granato, D., Raices, R. S. L., Freitas, M. Q., Sant'Ana, A. S., Esmerino, E. A., Pimentel, T. C., Silva, M. C., \& Cruz, A. G. (2021a). Can sucrose-substitutes increase the antagonistic activity against foodborne pathogens, and improve the technological and functional properties of sheep milk kefir? Food Chemistry, 351, 129290. http://dx.doi.org/10.1016/j.foodchem.2021.129290. PMid:33631613.

Larosa, C. P., Balthazar, C. F., Jonas, T., Guimarães, J. T., Rocha, R. S., Silva, R., Pimentel, T. C., Granato, D., Duarte, M. C. K. H., Silva, M. C., Freitas, M. Q., Cruz, A. G., \& Esmerino, E. A. (2021b). Sheep milk kefir sweetened with different sugars: sensory acceptance and consumer emotion profiling. Journal of Dairy Science, 104(1), 295300. http://dx.doi.org/10.3168/jds.2020-18702. PMid:33162085.

Lépine, A., \& de Vos, P. (2018). Synbiotic effects of the dietary fiber long-chain inulin and probiotic Lactobacillus acidophilus W37 can be caused by direct, synergistic stimulation of immune toll-like receptors and dendritic cells. Molecular Nutrition \& Food Research, 62(15), e1800251. http://dx.doi.org/10.1002/mnfr.201800251. PMid:29902355.

Lim, H. W., Kim, D. H., Jeong, D., Kang, I. B., Kım, H., \& Seo, K. H. (2019). Biochemical characteristics, virulence traits and antifungal resistance of two major yeast species isolated from kefir: Kluyveromyces marxianus and Saccharomyces unisporus. International Journal of Dairy Technology, 72(2), 275-281. http://dx.doi.org/10.1111/14710307.12582 .

Mitra, S. \& Ghosh, B.C. (2020). Quality characteristics of kefir as a carrier for probiotic Lactobacillus rhamnosus GG. International Journal of Dairy Technology, 73(2), 384-391. https://doi.org/10.1111/14710307.12664.

Oner, Z., Karahan, A. G., \& Cakmakc1, M. L. (2010). Effects of different milk types and starter cultures on kefır. Gida, 35, 177-182.

Ozyurt, H., \& Otles, S. (2014). Prebiotics: An Important Food Component for Metabolism. Academic Food J., 12, 115-123.

Pompei, A., Cordisco, L., Raimondi, S., Amaretti, A., Pagnoni, U. M., Matteuzzi, D., \& Rossi, M. (2008). In vitro comparison of the prebiotic effects of two inulin-type fructans. Anaerobe, 14(5), 280-286. http:// dx.doi.org/10.1016/j.anaerobe.2008.07.002. PMid:18713652.

Sarfraz, F., Farooq, U., Shaf1, A., Hayat, Z., Akram, K., \& Rehman, H. U. (2019). Hypolipidaemic effects of synbiotic yoghurt in rabbits. International Journal of Dairy Technology, 72(4), 545-550. http:// dx.doi.org/10.1111/1471-0307.12618.

Satır, G., \& Guzel-Seydim, Z. B. (2016). How kefir fermentation can affect product composition. Small Ruminant Research, 134, 1-7. http://dx.doi.org/10.1016/j.smallrumres.2015.10.022.

Saxelin, M., Grenov, B., Svensson, U., Fondén, R., Reniero, R., \& MattilaSandholm, T. (1999). The technology of probiotics. Trends in Food Science \& Technology, 10(12), 387-392. http://dx.doi.org/10.1016/ S0924-2244(00)00027-3.

Setyawardani, T., Sumarmono, J., Arief, I. I., Rahardjo, A. H. D., Widayaka, K., \& Santosa, S. S. (2020). Improving composition and microbiological characteristics of milk kefir using colostrum. Food Science and Technology (Campinas), 40(suppl 2), 699-707. http:// dx.doi.org/10.1590/fst.31719.

Sezen, F., \& Kocak, C. (2006, May 24-26). Developments in functional dairy products technology. In Food Congress. Ankara: Dairy Technology Department, Faculty of Agriculture, Ankara University.

Shafi, A., Naeem Raja, H., Farooq, U., Akram, K., Hayat, Z., Naz, A., \& Nadeem, H. R. (2019). Antimicrobial and antidiabetic potential of synbiotic fermented milk: a functional dairy product. International Journal of Dairy Technology, 72(1), 15-22. http://dx.doi. org/10.1111/1471-0307.12555.

Shafiee, G., Mortazavian, A. M., Mohammadifar, M. A., Koushki, M. R., Mohammadi, A., \& Mohammadi, R. (2010). Combined effects of dry matter content, incubation temperature and final $\mathrm{pH}$ of fermentation on biochemical and microbiological characteristics of probiotic fermented milk. African Journal of Microbiological Research, 4, 1265-1274. http://dx.doi.org/10.5897/AJMR.9000176.

Silveira, E. O., Lopes, J. H. No., Silva, L. A., Raposo, A. E. S., Magnani, M., \& Cardarelli, H. R. (2015). The effects of inulin combined with oligofructose and goat cheese whey on the physicochemical properties and sensory acceptance of a probiotic chocolate goat dairy beverage. Food Sci. Techno., 62(1), 445-451. http://dx.doi. org/10.1016/j.lwt.2014.09.056.

Simova, E., Beshkova, D., Angelov, A., Hristozova, T., Frengova, G., \& Spasov, Z. (2002). Lactic acid bacteria and yeasts in kefir grains and kefir made from them. Journal of Industrial Microbiology and Biotechnology, 28, 1-6. https://doi: 10.1038/sj/jim/7000186.

Swanson, K. S., Gibson, G. R., Hutkins, R., Reimer, R. A., Reid, G., Verbeke, K., Scott, K. P., Holscher, H. D., Azad, M. B., Delzenne, N. M., \& Sanders, M. E. (2020). The International Scientific Association for Probiotics and Prebiotics (ISAPP) consensus statement on the definition and scope of synbiotics. Nature reviews. Gastroenterology \& Hepatology, 17(11), 687-701. PMid:32826966.

Tamime, A. Y., \& Deeth, H. C. (1980). Yoghurt: technology and biochemistry. Journal of Food Protection, 43, 939-976.

Tomar, O., Akarca, G., Caglar, A., Beykaya, M., \& Gok, V. (2020). The effects of kefir grain and starter culture on kefir produced from cow and buffalo milk during storage periods. Food Science and Technology (Campinas), 40(1), 238-244. http://dx.doi.org/10.1590/fst.39418.

Ulberth, F. (1991). Headspace gas chomatos rafhic estimation of some yoghurt volatiles. Journal - Association of Official Analytical Chemists, 74, 630-634.

Ustundag, G. H., Altuntas, H., Soysal, Y. D., \& Kokturk, F. (2017). The effects of synbiotic "Bifidobacterium lactis B94 plus Inulin” addition on standard triple therapy of Helicobacter pylori eradication in 
children. Canadian Journal of Gastroenterology and Hepatology, 2017, 8130596. http://dx.doi.org/10.1155/2017/8130596.

Wszolek, M., Tamime, A. Y., Muir, D. D., \& Barclay, M. N. I. (2001). Properties of kefir made in Scotland and Poland using bovine, caprine and ovine milk with different starter cultures. LebensmittelWissenschaft + Technologie, 34(4), 251-261. http://dx.doi.org/10.1006/ fstl.2001.0773.

Xavier-Santosa, D., Bedania, R., Peregoc, P., Convertic, A., \& Saada, S. M. I. (2019). L. acidophilus La-5, fructo-oligosaccharides and inulin may improve sensory acceptance and texture profile of a synbiotic diet mousse. Food Science and Technology (Campinas), 105, 329-335.
Zendeboodi, F., Khorshidian, N., Mortazavian, A. M., \& da Cruz, A. G. (2020). Probiotic: conceptualization from a new approach. Current Opinion in Food Science, 32, 103-123. http://dx.doi.org/10.1016/j. cofs.2020.03.009.

Ziemer, C. J., \& Gibson, G. R. (1998). An overview of probiotics, prebiotics and synbotics in the functional food concept: perspectives and future strategies. International Dairy Journal, 8(5-6), 473-479. http://dx.doi.org/10.1016/S0958-6946(98)00071-5.

Zourari, A., Zourari, A., \& Anifantakis, E. M. (1988). Le kefir caracteres physico-chimiques, microbiologiques et nutritionnels. Technologie de production. Une Revue. Le Lait, 68(4), 373-392. http://dx.doi. org/10.1051/lait:1988424. 